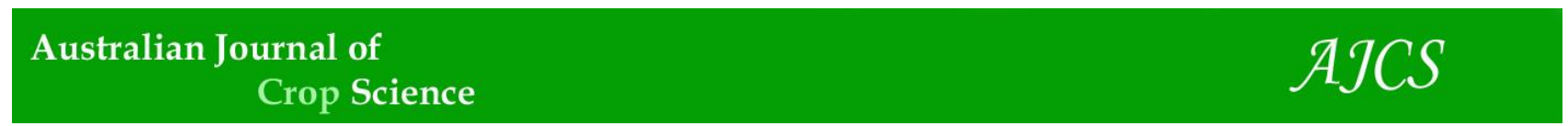

AJCS 14(07):1081-1087 (2020)

ISSN:1835-2707

doi: 10.21475/ajcs.20.14.07.p2218

\title{
Effects of post-harvest hot water treatments on the fungi contamination, physiology and quality of rock melon fruit
}

\author{
M.M. Abubakar ${ }^{1}$, M. Norida ${ }^{1,2 *}$, M.Y. Rafii ${ }^{1,3}$, J.J. Nakasha ${ }^{3}$ \\ ${ }^{1}$ Laboratory of Climate Smart Food Crop, Institute of Tropical Agriculture and Food Security, Universiti Putra \\ Malaysia \\ ${ }^{2}$ Department of Agriculture Technology, Faculty of Agriculture, Universiti Putra Malaysia \\ ${ }^{3}$ Department of Crop Science, Faculty of Agriculture, Universiti Putra Malaysia
}

*Corresponding author: noridamz@upm.edu.my

Abstract

During the postharvest management of fruits and vegetables, the losses range from 10 to $30 \%$ of the entire production. This is due to numerous causes, but the most important reason is infestation by fungi. Many synthetic fungicides are employed for postharvest treatment of fruit and vegetables throughout the world. However, fungicidal residues often represent a significant threat to human health. The current study examined the use of hot water treatments on rock melon fruit. Hot water treatments at $55^{\circ} \mathrm{C}$ was arranged into four treatments of different dipping periods of 0 minutes (control), 1 minute, 2 minutes, and 3 minutes. The postharvest hot water treatments on rock melon fruit were found to increase the shelf life up to 21 days by minimizing the weight loss, maintaining firmness, preventing the damage of sucrose, retaining the rind size, maintaining the fruit appearance, and reducing fungal infection. The one-minute dip was more effective than other treatments. The treatment successfully extends the shelf life of rock melon fruit quality for the market until three weeks of storage at $21 \pm 1{ }^{\circ} \mathrm{C}$ compared with the control, which was only stored for one week. The results showed the importance of hot water treatments as an alternative to fungicides or chemical treatments, which have a high risk to the health of consumers. Hot water treatment is economical and easier to access than the chemical treatments.

Keywords: hot water treatment, postharvest, disease severity. Abbreviations: HWT_hot water treatment.

\section{Introduction}

Rock melon (Cucumis melo L.) belongs to the Cucurbitaceae family, which comprises a variety of squashes and melons. It is a commercially significant crop in many countries, because it has a delightful and juicy taste with several nutritive values. It has captured a commercial awareness in more than a few regions such as the United States, Europe, and Asiatic countries (Sidik et al., 2012) Postharvest losses are projected in the range of 10 to $30 \%$ per year regardless of the use of current storing facilities and techniques (Singh et al., 2017). In rock melon fruits, the major setback is the postharvest management, and a high respiration rate and spoilage are the main factors affecting perishability (Syahidah et al., 2015). Over time, the use of heat, cold, and fungicide treatments has consistently suppressed the development pathogen and improved the shelf life. The loss of perishable products due to deficiencies of refrigeration in a developed country is $9 \%$; while in a developing country, it is $23 \%$. However, the total loss of fruits and vegetables in a developed country is $15 \%$, while in a developing country, it is 40\% (Diane et al., 2013).

Many fungicides such as Acibenzolar-S-methyl, Azoxystrobin, Copper sulfate, Chlorothalonil, and Zoxamide are employed today for the postharvest treatment of fruit and vegetables throughout the world (Fishel, 2016). Fungicide residues often represent a significant threat to human health, with unpredictable consequences for the trade, economy, and environment (Schirra et al., 2000). Postharvest pesticides are have a high rate of recurrence and high concentrations because they are applied later than insect killers that are applied on-the farm, and they are usually not exposed to rain, wind, high temperature or sunlight, which could help in degradation of the residues (Zia et al., 2009).

With the current change in emphasis from the use of chemical treatments, interest in heat disinfection has been revived (Spotts and Chen, 1987). Currently, there has been growing interest in the use of heat treatments on fresh postharvest produce to control insect pests, prevent fungal rots, and manipulate the ripening of the commodity. There has been increased public demand for the decrease of postharvest use of fungicides against insects and diseases (Fallik, 2004).

Treatments with hot water for the control of postharvest decline are regularly applied for a limited time, since only the surface of the product requires heating (Postrecolte et al., 2007). Many fruits and vegetables are tolerant of exposure of water temperatures $\left(50-60^{\circ} \mathrm{C}\right)$ for up to $10 \mathrm{~min}$. However, such a long duration of dipping is not required for the control of most postharvest pathogens (Asio and 
Cuaresma, 2016) Postharvest treatment with hot water is thought to reduce decay incidence by restraining the sites of fungal penetration into the fruit and to keep fruit firmer by reducing weight loss (Fallik et al., 1999).

A two minute dip of citrus at $53^{\circ} \mathrm{C}$ has been found to decrease the sensitivity of oranges and other fruit to chilling injury (Erkan et al., 2005). Ben (2003) also reported delay in ripening and increase of shelf life of tomato when treated with hot water. In mature green tomato, the ripening was delayed when exposed to heat treatment (Lurie et al., 1997). The authors explained that there was a delayed degradation rate of peroxidase, which caused it to maintain resistance against decay pathogens (Lurie et al., 1997).

The method of action of hot water dips on the deterioration of fresh produce has been reported to be a direct interaction with the fungi, perhaps by killing un-germinated spores and reducing germ tube elongation, thus slowing disease development in storage (Janisiewicz and Conway, 2010). Previously, it has been reported that failure or delay in rot development is the result of the slow growth of distorted hyphae germinated from the spores inoculating heat treated fruit (Gunes et al., 2000). Similar observations have been made by Schirra (1997) and Wijeratnam et al. (2005), who stated that HWT have a direct outcome of deactivating or killing developing spores or slowing germ tube elongation. An investigation by Schirra et al. (2000) found a negligible number of fungal spores were eliminated or removed from wound inoculated fruit following a $2 \mathrm{~min}$ wash with hot water at $52^{\circ} \mathrm{C}$. They suggested a hot water dip at $55^{\circ} \mathrm{C}$ for $1-$ $2 \mathrm{~min}$ as optimal for a postharvest anti-fungal treatment for 'Galia' melons. However, 'Galia' melon fruit dipped in hot water above $55^{\circ} \mathrm{C}$ and for more than $2 \mathrm{~min}$, showed damage to the skin of the fruit due to overheating and longer dip times (Mayberry and Hartz, 1992). Although most reports have focused on the positive response of commodities to heat treatment, it is essential to optimise a method for a specific crop. As mentioned by Lurie (1998a), tissue damage can happen when applying heat treatments. The present study investigated the effectiveness of different hot water soaking periods as treatments of the physiological characteristics of rock melon in order to reduce the usage of synthetic chemicals. The results could be a reference point for relevant parties to take necessary actions in providing a favorable treatment for rock melon storage and providing an affordable control of diseases.

\section{Result and discussion}

\section{Rock melon fruit weight loss:}

Postharvest weight loss has an excessive effect on fruit quality and is the primary cause of deterioration during storage. The results for hot water treatment at three weeks showed a significant difference among the treatments (Table 1). Those that were in the control had $31 \%$ weight loss, which was significantly higher compared to other treatments. This was followed by the 3-minute dipping time, which had $19.5 \%$ of weight loss. However, there was no significant difference in weight loss between 1-minute and 2-minute dipping times, with the lowest weight losses of $12.25 \%$ and $10 \%$, respectively. The reduction of weight loss in the treatments compared to the control was attributed to the hot water treatment melting the wax and closing cracks while reducing weight loss, delaying ripening and slowing the degradation rate of peroxidase (Lurie et al., 1997). The explanation from previous research (Lurie et al., 1997) is in line with our finding on hot water treatment of rock melon fruit. Similarly, llić and Fallik (2007) mentioned that heat treated 'Galia' melon fruit had less weight loss than untreated fruits.

A significant positive perfect correlation was observed between hot water dipping time and weight loss (Table 2). This shows that the longer the dipping time, the higher the weight loss, which may be attributed to the temperature of the water affecting the cell walls of the fruit and faster ripening of the fruit leading to degradation and weight loss. Jacobi et al. (2001) also found that in hot water treatments of 'Kensington' mangoes where the fruit core temperature was raised to $15 \mathrm{~min}$ at $47^{\circ} \mathrm{C}$, the weight loss increased to $50 \%$.

\section{Firmness of fruit within treatments:}

The observations (Table 1) on firmness display a significantly higher firmness on the fruits treated for 1-minute with a firmness value of $7.75 \mathrm{~N}$, while the control had a significantly lower firmness value of $1.7 \mathrm{~N}$. However, there was also a significant firmness difference between the 2- and 3-minute treated fruits with the values of $5.25 \mathrm{~N}$ and $3.25 \mathrm{~N}$, respectively. The results suggest that hot water treatment offers benefits in controlling fruit firmness, but prolonging the period can cause adverse effects on fruit firmness. However, the results were much better than those in the control group were. These results were supported by Mohammed et al. (2017), where melons lost their firmness when treated in hot water at $55^{\circ} \mathrm{C}$ for more than $90 \mathrm{sec}$. Fruit firmness is one of the most significant quality variables. Therefore, by the control having the lowest firmness compared to the other treatments, this shows that the hot water treatment was active in maintaining the firmness of the fruit during storage by delaying ripening, sealing the cracks, and melting the waxes ( Fallik, 2004). Similarly, Klein (1991) suggested that treating fruit in hot water results in limited injury to the respiratory mechanism, which in turn delays ripening and ultimately extends the storage life of hot water treated produce. A significant negative correlation was shown between weight loss and firmness, Brix, rind thickness, and appearance. This shows that the higher the weight loss, the lower the fruit firmness. Fruit quality depreciated during storage as weight loss increased. The firmness decreased, and this was the greatest significant limiting value factor for most fruits assessed (Unes et al., 2007). However, when water is lost from fruit, it leads to high risk of deterioration on the fruit quality, which may reduce the strength of the cells on the skin and reduce firmness. Softening of fruit is triggered by the damage of pectic substances in the central lamella of the cell wall that leads to the loss of cell wall integrity, thus causing the loss of firmness and shrinkage (Rupinder and Mahajan, 2014). Similarly, Miccolis and Saltveit (1995) stated that the softening of melon in storage was related to moisture loss.

\section{Brix index of rock melon fruit}

The sugar content is one of the most essential quality traits perceived by consumers in rock melon fruits. The USDA (1981) suggested that the lowest TSS of honeydew melons should be equivalent to or more than $8^{\circ}$ Brix. For the profitable market, the TSS of melon fruit should be more than or equivalent to $10^{\circ}$ Brix, and beneath that level, 
Table 1. The main effect of hot water treatment on rock melon fruits during storage.

\begin{tabular}{|c|c|c|c|c|c|c|}
\hline Treatment & Weight loss (\%) & Firmness (N) & brix index $\left({ }^{\circ}\right.$ Brix $)$ & $\begin{array}{l}\text { Rind thickness } \\
(\mathrm{mm})\end{array}$ & $\begin{array}{c}\text { Appearance (1- } \\
5)\end{array}$ & $\begin{array}{c}\text { Fusarium } \\
\text { disease (1-5) }\end{array}$ \\
\hline control & $31.0 \pm 1.35 a$ & $1.7 \pm 0.47 d$ & $6.0 \pm 0.70 b$ & $2.0 \pm 0.25 b$ & $1.0 \pm 0.00 c$ & $4.25 \pm 0.25 a$ \\
\hline $1 \mathrm{~min}$ & $12.25 \pm 1.31 \mathrm{c}$ & $7.75 \pm 0.47 a$ & $11.25 \pm 0.25 a$ & $3.25 \pm 0.25 a$ & $4.0 \pm 0.00 a$ & $1 \pm 0.00 \mathrm{~b}$ \\
\hline $2 \min$ & $10.0 \pm 0.70 c$ & $5.25 \pm 0.25 b$ & $11.0 \pm 0.40 a$ & $3.25 \pm 0.25 a$ & $3.0 \pm 0.40 \mathrm{~b}$ & $1 \mathrm{~b} \pm 0.00 \mathrm{~b}$ \\
\hline $3 \mathrm{~min}$ & $19.5 b \pm 3.13 b$ & $3.25 \pm 0.25 c$ & $10.75 \pm 0.25 a$ & $2.5 \pm 0.50 \mathrm{ab}$ & $3.0 \pm 0.40 \mathrm{~b}$ & $1.5 \pm 0.50 \mathrm{~b}$ \\
\hline
\end{tabular}

Table 2. The correlation between the parameters on hot water treatment of rock melon fruits.

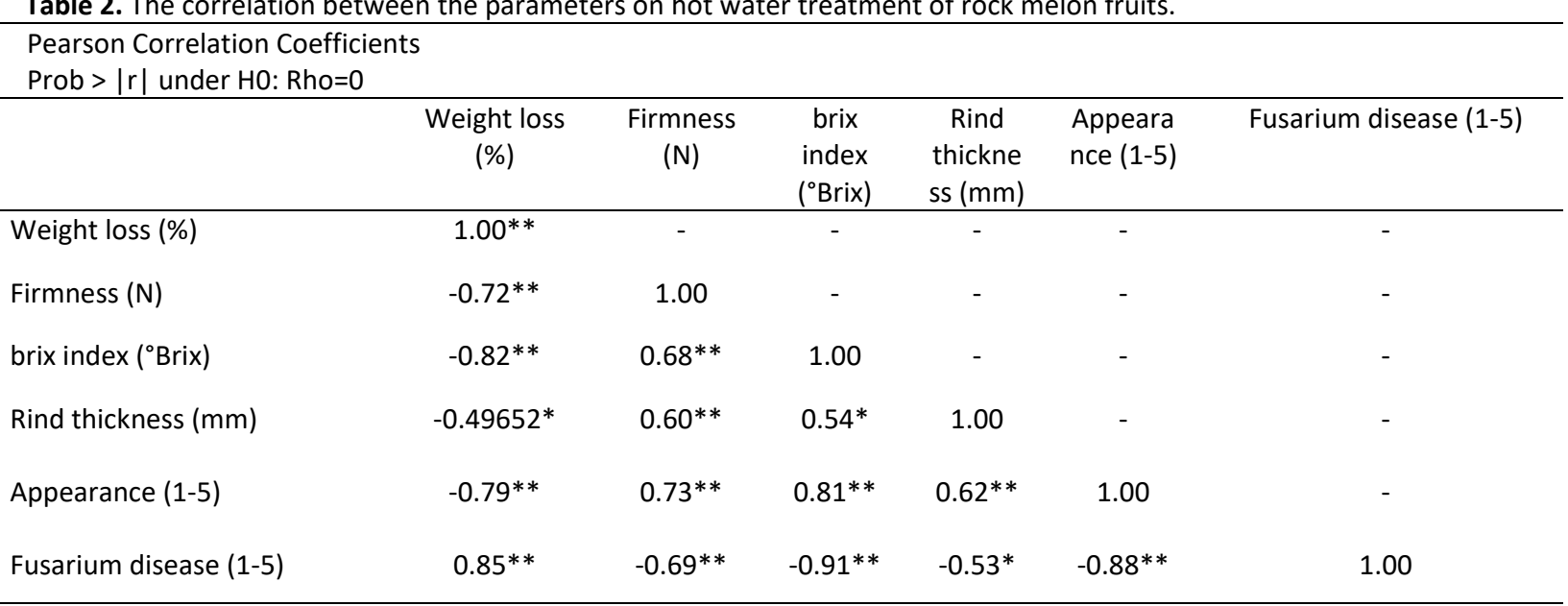

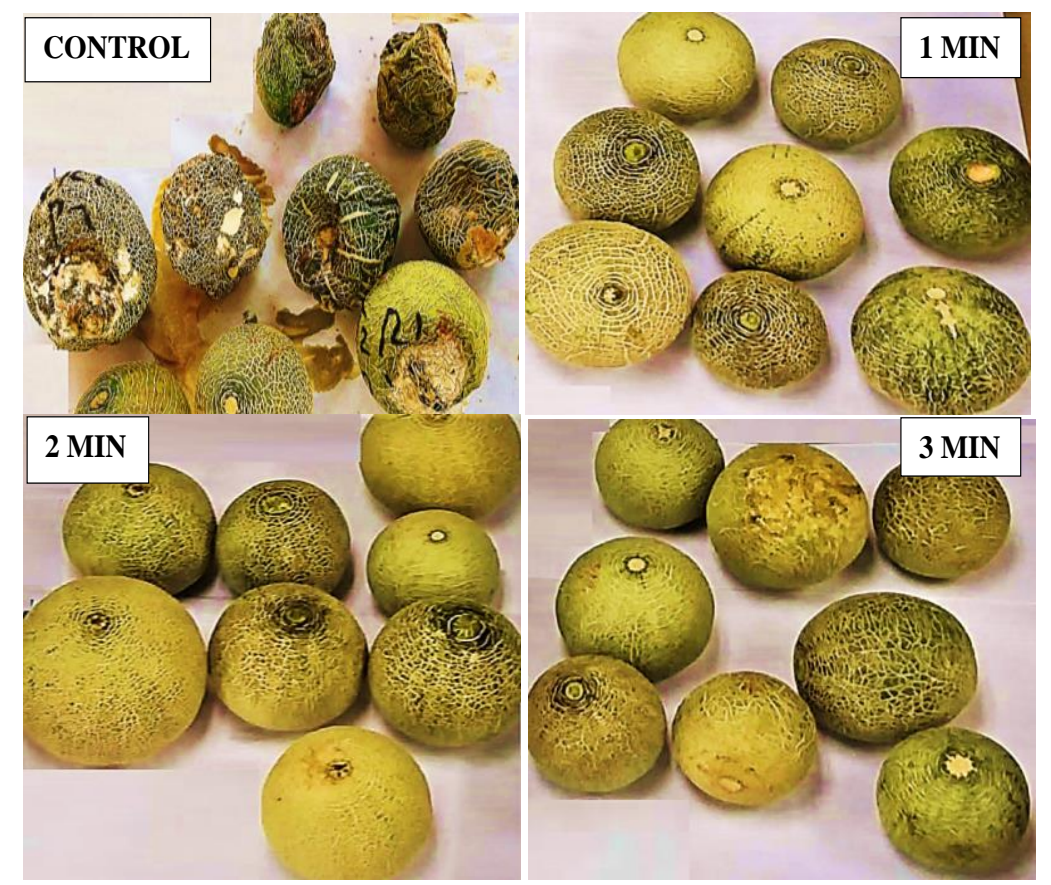

Fig 1. Shown the photograph of control, $1 \mathrm{~min}, 2 \mathrm{~min}$, and 3min of rock melon fruit after three weeks storage on hot water treatment at $55^{\circ} \mathrm{C}$.

melons are not generally suitable for marketing (United Nation Economic Commission for Europe, 2006).
The results for the Brix index with hot water treatment dipping time shows a significant difference at $P \leq 0.5$ between control and other treatments, where the control 
had the lowest value of $6.0^{\circ} \mathrm{Brix}$. However, there was no significant Brix difference among all the treated rock melons where ranged from 10.75 to $11.25^{\circ}$ Brix (Table 1). The lower Brix index for the control compared to other treatments was attributed to the hot water treatment imposed on the fruit. Postharvest dipping of some commodities, such as muskmelons, in hot water improves the sugar content by preventing the damage of sucrose that occurs in non-heated fruit throughout storage (Lurie, 1998b). Similarly, Jacobi et al. (2000) found that hot water treatment at $40^{\circ} \mathrm{C}$ increased the Brix index of mango fruit.

\section{Rind thickness of fruits}

Water loss from fruit during storage results in shrinkage and fruit softening. The results (Table 1 ) for the rind thickness of rock melon fruits showed a significantly lower rind size for the control compared to other treatments, with a size of 2.0 $\mathrm{mm}$, but there was no significant difference at $P \leq 0.5$ between 1- and 2-min dipping times, with the largest rind thicknesses of $3.25 \mathrm{~mm}$ and $3.25 \mathrm{~mm}$, respectively. Meanwhile, the 3-minute treatment also had a narrow rind, but it was not as small as the control was. The observation of rind thickness showed that the control had the lowest rind, which is attributed to the water loss and shrinkage, confirming that hot water treatment seals openings and reduces water loss from the fruit. Principal losses in storage are due to shrinkage, and shrinkage is due to the loss of water from the produce (Gopinadhan et al., 2008).

\section{Appearance of fruit}

The observation on appearance of the fruit is presented in Table 1. Appearances showed significant differences at $P \leq$ 0.5 between control and other treatment having 1.0 according to the scale of Aharoni et al. (1997). However, 1min dipping time had a significantly higher scale value of 4.0, with no significant differences between 2- and 3-min dipping times, which had a scale of 3.0. There was a significant difference between the 1-min and other treatments respectively. The reduced appearance quality for the control compared to the other treatments was attributed to the hot water treatment. Appearance is an essential aspect in marketing fruits based on quality, and it was evident that employing hot water treatments significantly reduced deterioration for numerous fresh harvested fruit (Ben et al., 2000; Fallik et al., 2000; Porat et al., 2000). The result also shows 1-min to have the best appearance compared against the other treatments. This may be attributed to the increase in time of the hot water dip, which may have led to the damage of cells on the skin and was shown in the significant difference with less dipping time. Mayberry and Hartz (1992) also suggested a hot water dip at $55^{\circ} \mathrm{C}$ for $1-2$ min as optimal for a postharvest anti-fungal treatment for 'Galia' melons. However, 'Galia' melon fruit dipped in hot water above $55^{\circ} \mathrm{C}$ and for more than two minutes had damaged skins due to overheating and longer dip time. The results in Table 2 also show a significant positive correlation between weight loss and the appearance of fruit; the higher the weight loss, the poorer the appearance of the fruit. When weight loss increases, the appearance quality declines at a faster frequency, and the fruit appear undesirable for marketing (Unes et al., 2007).

\section{Fusarium disease severity on the fruit:}

Observations on hot water treatment dipping time against fusarium infection on rock melon fruit showed a significant difference at $P \leq 0.5$ between the control and other treatments, where control has the highest disease severity of 4.25. However, there was no significant difference among all the treated fruits (Table 1). Postharvest treatment with hot water is thought to reduce decay incidence by limiting the sites of fungal penetration into the fruit and to keep fruit firmer due to less weight loss (Fallik et al., 1999). Reduced fungal infection after hot water application may be due to recrystallization or melting of the wax surface, which seals the micro openings through which pathogens could get an entry. The current observation shows the lower quality of fruit and high infection of disease in the control compared to other hot water treatments of fusarium fungi. A hot water treatment dip of $1 \mathrm{~min}$ at $52^{\circ} \mathrm{C}$ reduced the rate of decay growth in litchi (Olesen et al., 2004). Similarly, Wijeratnam et al. (2005) also suggested that a 3-min hot water treatment at $54^{\circ} \mathrm{C}$, applied to the peduncle of pineapple fruit was controlled the occurrence of black rot. Results in Table 2 also show a significant positive correlation between weight loss and fusarium disease severity. This also shows that the higher the weight loss, the higher the disease severity on the surface of the fruit, because the fruit quality had already been reduced by weight loss, which makes it favorable for the disease to affect the fruit. Weight loss was attributed to high respiration by the fruit, which leads to the loss of water to the air, while high respiration also makes the environment favorable to the organisms that can affect the fruit. Water loss on fresh fruits happens through transpiration, which distresses saleable weight, appearance, juiciness, crispness, and texture quality (Wu, 2010).

\section{Materials and methods}

\section{Plant material}

Rockmelon $F_{1}$ hybrid, 'Glamour' seed variety was sowed and kept under a controlled environment for two weeks before transplanting the seedlings into polybags in a net-house. Controlled fertigation/fertilizer mix was used for all the plants. Mature fruit were harvested early in the morning 75 days after transplanting, and the fruit were transported to the laboratory.

\section{Experimental design}

The experiment was carried out in a Completely Randomized Design (CRD) with three replications. The hot water treatment at $55^{\circ} \mathrm{C}$ was arranged into four treatments examined in different dipping periods of 0 minute (control), 1 minute, 2 minutes, and 3 minutes.

\section{Hot water treatment setup}

The hot water treatment was carried out after pre-cooling the fruit for 12 hours at room temperature, the water bath was set at $55^{\circ} \mathrm{C}$, and the fruit were soaked for either 1,2 or 3-minutes. These were compared with the fruit that did not undergo the hot water treatment. The treated fruit were allowed to air dry for 30-minutes. All fruit were then stored for 21 days at $21^{\circ} \mathrm{C} \pm 1$ at $90 \% \mathrm{RH}$. 


\section{Conduction of experiment}

The weights of all fruit were recorded immediately after the hot water treatment using an electric automatic weighing balance, and later recorded every week, according to the treatment arrangement, to obtain the weight loss of each fruit. The Brix index (sugar content) of all the fruit was measured using an electronic digital refractometer by dropping the squeezed juice on top of the sensor to obtain the amount of sugar in each fruit as a percentage. The rind thickness of each fruit was obtained after cutting the fruit into two and with a digital Vernier caliper, the size of the green part at the edge of the flesh was measured by shifting the head of the Vernier clipper to obtain the size in millimeters.

Fruit firmness was measured with Instron Universal Testing Machine (Model 5543 P5995, USA) as the force essential to enter $10 \mathrm{~mm}$ inside the fruit by means of a probe with a diameter of $6 \mathrm{~mm}$. The mechanism was set with the firmness mode at the speed of $20 \mathrm{~mm} / \mathrm{min}$. The reading was documented on three positions as at the top, middle and under of the inner flesh of the fruit, and the result was expressed in terms of force recorded in Newtons (N), according to the methods of Khaliq et al. (2016). The appearance of fruit was evaluated visually, regarding the freshness of the fruit, decay, and skin blemishes, on a scale of $1-5$ with 1 being poor; 3 being good; and 5 being of excellent quality. Fruit with an assessment of less than 2.5 was considered unfit for marketing, following the method described by Aharoni et al. (1997), and the effects of hot water treatment on fungi were reported where observed.

\section{Fungi sample preparations and fruit infection}

Fusarium oxysporum was collected from an infected fruit and transported to the laboratory. Rinsing chemicals were prepared with $7.7 \mathrm{~mL}$ of (sodium hypochlorite 13\%) mixed with distilled water up to $100 \mathrm{~mL}$, and $50 \%$ alcohol was also prepared. The infected location of the fruit was cut out and rinsed in the sodium hypochlorite solution prepared for 30 sec and rinsed in 50\% alcohol for $1 \mathrm{~min}$, then rinsed in distilled water and placed in the prepared PDA (potato dextrose agar) and incubated at $25^{\circ} \mathrm{C}$ for four days.

The cultured fungi were suspended in sterile distilled water with Tween80, and the suspension was adjusted to $10^{6}$ Fusarium conidia/mL using a hemocytometer. The fruits were wounded, and $5 \mathrm{~mL}$ of the conidial sample was sprayed on the wounded location and allowed to dry for $12 \mathrm{~h}$ before subjecting it to the hot water treatment.

\section{Fusarium disease severity scale on fruit}

Estimates of disease severity on the fruit were based on the number and diameter of lesions according to a 5-point scale following the method described by Van Hung et al. (2010):

$1=$ No disease

$2=$ One lesion less than $1 \mathrm{~cm}$ in diameter

$3=$ One lesion between a diameter of $1-3 \mathrm{~cm}$, or two lesions each with a diameter less than $2 \mathrm{~cm}$

$4=$ One lesion larger than $3 \mathrm{~cm}$ but smaller than $3 \mathrm{~cm}$, or two lesions each larger than $2 \mathrm{~cm}$ but smaller than $3 \mathrm{~cm}$

$5=$ One lesion larger than $5 \mathrm{~cm}$ or more than 3 lesions.

\section{Statistical analysis}

The experimentation was conducted in a Completely Randomized Design (CRD) with three replications. Data were subjected to analysis of variance (ANOVA), and means were compared with LSD $(P \leq 0.05)$ using SAS 9.4 software.

\section{Conclusion}

In conclusion, hot water treatment might prolong the shelf life of rock melon fruit by reducing weight loss, maintaining firmness, increasing Brix, maintaining rind thickness, increasing juice content, maintaining a good appearance, and decreasing fungal diseases on the fruit while storing it up to three weeks at $21^{\circ} \mathrm{C}$. Among the dipping times, the study also significantly showed the relationship between treats and hot water dipping time, which confirms that dipping times in water at $55^{\circ} \mathrm{C}$ should not be longer than 2 $\mathrm{min}$, because the result has shown a reduction in quality as the time increases. The results show the importance of hot water treatment as an alternative to fungicides or chemical treatments, which have a high risk for the health of consumers and hot water treatment is economical and easier to access than the chemical treatments. However, further investigation is needed on the inhibition mechanism of ethylene synthesis by HWT. Ethylene is also related to disease occurrence, as the alteration in ethylene emission is a response to numerous pathogen infections in fruits.

\section{Acknowledgments}

The authors wish to thank the Ministry of Education of Malaysia for supporting this project under HICoE grant.

\section{References}

Aharoni Y, Fallik E, Copel A, Gil M, Grinberg S, and Klein J D (1997). Sodium bicarbonate reduces postharvest decay development on melons. Postharvest Biology and Technology. 10(3): 201-206.

Asio L G, Cuaresma F D (2016). A Review of Postharvest Treatments to Maintain Mango ( Mangifera Indica $L$.) Quality. Annals of Tropical Research. 93: 81-93.

Ben-Yehoshua S, Peretz J, Rodov V, Nafussi B, Yekutieli O, Wiseblum A, Regev R (2000). Postharvest application of hot water treatment in citrus fruits: The road from the laboratory to the packaging-house. Acta Horticulturae. 518: 19-28.

Ben-Yehoshua S (2003). Effects of postharvest heat and UV applications on decay, chilling injury and resistance against pathogens of citrus and other fruits and vegetables. Acta Horticulturae. 599: 159-173.

Diane M DuBois, H C-T D (2013). Use of cold chains for reducing food losses in developing countries. The Postharvest Education Foundation. 13: 1-16.

Erkan, M P, Mustafa W, Chien Y (2005). Hot water and curing treatments reduce chilling injury and maintain post-harvest quality of 'Valencia' oranges. International Journal of Food Science and Technology. 40: 91-9.

Fallik E (2004). Prestorage hot water treatments (immersion, rinsing, and brushing). Postharvest Biology and Technology. 32(2): 125-134. 
Fallik E, Aharoni Y, Copel A, Rodov V, Tuvia-Alkalai S, Horev B, Regev R (2000). Reduction of postharvest losses of Galia melon by a short hot-water rinse. Plant Pathology. 49(3): 333-338.

Fallik E, Grinberg S, Alkalai S, Yekutieli O, Wiseblum A, Regev R, Bar-Lev E (1999). A unique rapid hot water treatment to improve storage quality of sweet pepper. Postharvest Biology and Technology. 15(1): 25-32.

Fishel F M (2016). Storage Limitation Statements: Temperature Fungicides. UF/IFAS Extension. 122: 1-7. Retrieved from http://edis.ifas.ufl.edu.

Gopinadhan P, Murr D P, Handa A K, Lurie S (2008). Postharvest Biology and Technology of Fruits, Vegetables, and Flowers (1st ed). Wiley-Blackwell Publishing. 413-497. Retrieved from www.wiley.com/wiley-blackwell.

Gunes G, Watkins C B, Hotchkiss J H (2000). Effects of irradiation on respiration and ethylene production of apple slices. Journal of the Science of Food and Agriculture. 80(8): 1169-1175.

Ilić Z, Fallik E (2007). Influence of post-harvest treatments on quality of Galia melons during low temperature storage. Acta HorticulturaeHorticulturae. 729: 417-421.

Jacobi K K, Macrae E A, Hetherington S E (2000). Effects of hot air conditioning of 'Kensington' mango fruit on the response to hot water treatment. Postharvest Biology and Technology. 21: 39-49.

Jacobi K K, Mac, R E A, Hetherington S E (2001). Loss of heat tolerance in "Kensington" mango fruit following heat treatments. Postharvest Biology and Technology. 21(3): 321-330.

Janisiewicz W J, Conway W S (2010). Combining biological control with physical and chemical treatments to control fruit decay after harvest. Stewart Postharvest Review. 6(1): 1-16.

Khaliq G, Mohamed M T M, Ding P, Ghazali H M, Ali A (2016). Storage behaviour and quality responses of mango (Mangifera indica L.) fruit treated with chitosan and gum arabic coatings during cold storage conditions. International Food Research Journal. 23: 141-S148.

Klein J (1991). Postharvest heat treatment and fruit quality. Postharvest News and Information. 2: 15-19.

Lurie S (1998a). Postharvest heat treatments. Postharvest Biology and Technology. 14(3): 257-269.

Lurie S (1998b). Postharvest heat treatments of horticultural crops. Horticultural Reviews. 22: 91-121.

Lurie S, Fallik E, Handros A, Shapira R (1997). The possible involvement of peroxidase in resistance to Botrytis cinerea in heat treated tomato fruit. Physiological and Molecular Plant Pathology. 50(3): 141-149.

Mayberry K S, Hartz T K (1992). Extension of Muskmelon Storage Life through the Use of Hot Water Treatment and Polyethylene Wraps. Hortscience. 27. 324-326.

Miccolis V, Saltveit M (1995). Influence of storage period and temperature on the postharvest characteristics of six melon (Cucumis melo L., Inodorus Group) cultivars. Postharvest Biol. Technol. 5: 211-219

Mohammad S M, Rajabipour A, Mobli H (2017). Determination of Bruise Incidence of Pomegranate Fruit under Drop Case. International Journal of Fruit Science. 17(3): 296-309.
Olesen T, Nacey L, Wiltshire N, O'Brien S (2004). Hot water treatment for the control of rots on harvested litchi (Litchi chinensis Sonn.). Postharvest Biology and Technology. 32: 135-146

Porat R, Pavoncello D, Peretz J, Weiss B, Daus A, Cohen L, Lurie $S$ (2000). Induction of resistance to Penicillium digitatum and chilling injury in "Star Ruby" grapefruit by a short hot-water rinse and brushing treatment. Journal of Horticultural Science and Biotechnology. 75(4): 428-432.

Postrecolte I, Canada A, Raghavan V G S (2007). Heat treatment application to increase fruit and vegetable quality. Postharvest Biology and Technology. 3: 1-8.

Rupinder S, Mahajan B V C (2014). Effect of packaging films on shelf life and quality of kinnow fruits packed in consumer packages. International Journal of Farm Sciences. 4(1): 92-98.

Schirra G (1997). Storage performance of Fortune mandarins following hot water dips. Postharvest Biology and Technology. 10: 229-238.

Schirra M, D’Hallewin G, Ben-Yehoshua S, Fallik E (2000). Host-pathogen interactions modulated by heat treatment. Postharvest Biology and Technology. 21(1): 71-85.

Sidik N J, Hashim S N, Mohd Y S, Abdullah S (2012). Characterization of Plant Growth, Yield and Fruit Quality of Rock melon (Cucumis melo) Cultivars Planted on Soilless Culture. Journal of Plant Sciences. 7(5): 186193.

Singh et al (2017). Impact of postharvest diseases and their management in fruit crops: an overview. Innovative Association. 6(5): 749-760.

Spotts A R, Chen P M (1987). Prestorage heat treatment for control of decay of pear fruit. Postharvest Pathology and Mycotoxins. 77(11): 1578-1582.

Syahidah K, Rosnah S, Noranizan M A, Zaulia O, Anvarjon A (2015). Quality changes of fresh cut cantaloupe (Cucumis melo L. var Reticulatus cv. Glamour) in different types of polypropylene packaging. International Food Research Journal. 22(2): 753-760.

Unes, CEcilia N, Jean-Pierre E (2007) Relationship between Weight Loss and Visual Quality of Fruits and Vegetables. University of Florida-IFAS, Food Science and Human Nutrition Department, Gainesville. 120: 235-245.

United Nation Economic Commission for Europe (2006) Melon. UNECE Standard FFV-23 Concerning Marketing and Commercial Quality Control of MELONS 2006 edition. United Nations. New York.

USDA. 1981. U.S. standards for grades of honeydew and honey ball type melons. USDA Agricultural Marketing Service, Fresh Fruit Division Fresh Products Branch. Washington DC. 3.

Van Hung D, Morris S, Mcconchie R, Tanaka F, Hamanaka D, Uchino T (2010). Rock melon (Cucumis melo L.) fruit ripening and postharvest quality following application of aminoethoxyvinylglycine. Journal of the Faculty of Agriculture, Kyushu University. 55(2): 281-285.

Wijeratnam R S W, Hewajulige I G N Abeyratne N (2005). Postharvest hot water treatment for the control of Thielaviopsis black rot of pineapple. Postharvest Biology and Technology. 36(3): 323-327. 
Wu C T (2010). An overview of postharvest biology and technology of fruits and vegetables. In. Workshop on Technology on Reducing Postharvest Losses and Maintaining Quality of Fruits and Vegetables. 2-11 2010. Available at: www.ir.tari.gov.
Zia M S, Muhammad Q, Jamil K M (2009). Pesticide Residue in the Food Chain and Human Body inside Pakistan. Journal of the Chemical Society of Pakistan. 31: 2-7. 